\title{
Growth hormone directly inhibits leptin gene expression in visceral fat tissue in fatty Zucker rats
}

\author{
O Isozaki, T Tsushima, M Miyakawa, Y Nozoe, H Demura and \\ H Seki ${ }^{1}$
}

Department of Medicine, Institute of Clinical Endocrinology, Tokyo Women's Medical College, Tokyo 162-8666, Japan

${ }^{1}$ Sumitomo Pharmaceuticals Research Center, Osaka 544-0022, Japan

(Requests for offprints should be addressed to O Isozaki, Department of Medicine, Institute of Clinical Endocrinology, Tokyo Women's Medical College, 8-1 Kawada-cho, Shinjuku-ku, Tokyo 162-8666, Japan)

\begin{abstract}
Growth hormone $(\mathrm{GH})$ is known to interact with adipose tissue and to induce lipolysis. Adipocytes produce leptin which regulates appetite and energy expenditure. In order to elucidate the role of $\mathrm{GH}$ in leptin production, we studied the effect of $\mathrm{GH}$ on leptin gene expression and body fat in fatty Zucker rats, a model of obesity with resistance to both leptin and insulin. Recombinant human GH administered subcutaneously at $0.5 \mathrm{mg} / \mathrm{kg}$ per day (low dose) as well as at $1.65 \mathrm{mg} / \mathrm{kg}$ per day (high dose)
\end{abstract}

reduced leptin mRNA levels in epididymal fat tissue but not in subcutaneous fat tissue after 7 days. GH administration only at the high dose reduced percentage body fat. Insulin-like growth factor-I infusion $(200 \mu \mathrm{g} / \mathrm{kg}$ per day) did not change percentage body fat or leptin mRNA levels in epididymal fat. These observations suggest that $\mathrm{GH}$ directly interacts with adipose tissue and reduces leptin gene expression in visceral fat tissue.

Journal of Endocrinology (1999) 161, 511-516

\section{Introduction}

Growth hormone (GH) has been reported to have a number of metabolic actions on peripheral tissues in addition to its growth-promoting effect which is mediated by insulin-like growth factor-I (IGF-I) production (Thorner et al. 1992). In adipose tissue, GH is known to promote lipolysis and to reduce fat deposition (Thorner et al. 1992). The lipolytic action of GH has already been established (Fain et al. 1965, Goodman 1968). Moreover, $\mathrm{GH}$-deficient patients often have an associated increase in body fat mass, and GH treatment reduces the fat mass especially in intra-abdominal adipose tissue (Deoer et al. 1995). Thus GH plays an important role in the regulation of adiposity. The obesity gene was isolated by positional cloning, and its gene product, leptin, has been characterized (Zhang et al. 1994). Leptin is expressed mainly in adipocytes, and its functional receptor is highly expressed in the hypothalamus (Tartaglia et al. 1995). A number of studies have revealed the role of leptin as a negative feedback signal, which reflects body adiposity by acting at the hypothalamic level. They also demonstrated that leptin expression is likely to fluctuate in response to a number of factors including nutritional and disease conditions (Campfield et al. 1996). These observations suggest a possible role for $\mathrm{GH}$ in the regulation of leptin expression in fat tissues. Therefore, an understanding of the inter- action between GH and leptin may be very helpful for the treatment of obesity and may clarify the mechanism of obesity in patients with growth hormone deficiency.

The Zucker rat is a strain of obese rat in which recessive homozygous individuals $(f a / f a)$ have obesity and hyperlipidemia. Recently the molecular defect in these rats has been shown to be similar to that in $d b / d b$ mice, which also carry a loss-of-function mutation in the leptin receptor (Chua et al. 1996). Leptin mRNA levels in the fat tissue of the rats are increased, and these animals are resistant to leptin treatment, a condition often observed in obese humans. Moreover, the synthesis and secretion of GH in these animals decrease after the onset of obesity, as seen in obese humans (Ahmad et al. 1990). The decrease in GH secretion is not a primary event but may play a role in the persistence of obesity. Interestingly hyperinsulinism develops in these rats before the secondary decrease in $\mathrm{GH}$ secretion, as in children with exogenous obesity, and they show normal linear growth and normal circulating levels of IGF-I despite the decrease in GH levels. Therefore, Zucker rats are a good model for early-onset exogenous obesity in humans, as well as being a useful system in which to study the role of GH in obesity. In the present study we examined the effects of $\mathrm{GH}$ on leptin gene expression and adiposity in fatty Zucker rats. 


\section{A. Low-dose treatment}
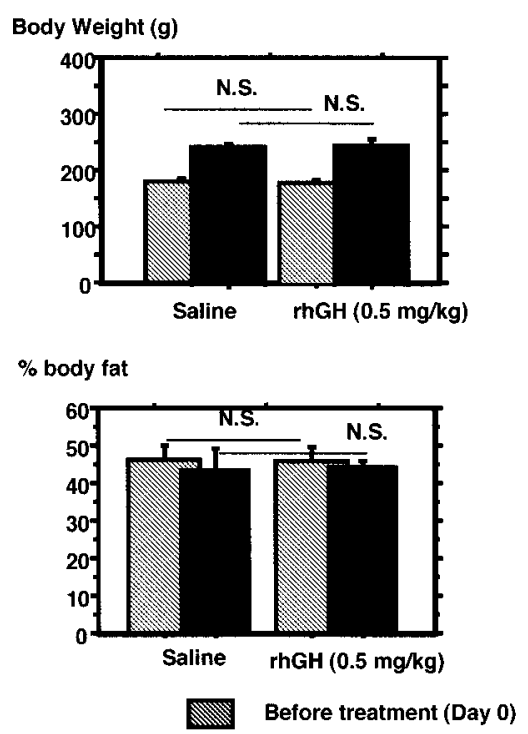

B. High-dose treatment

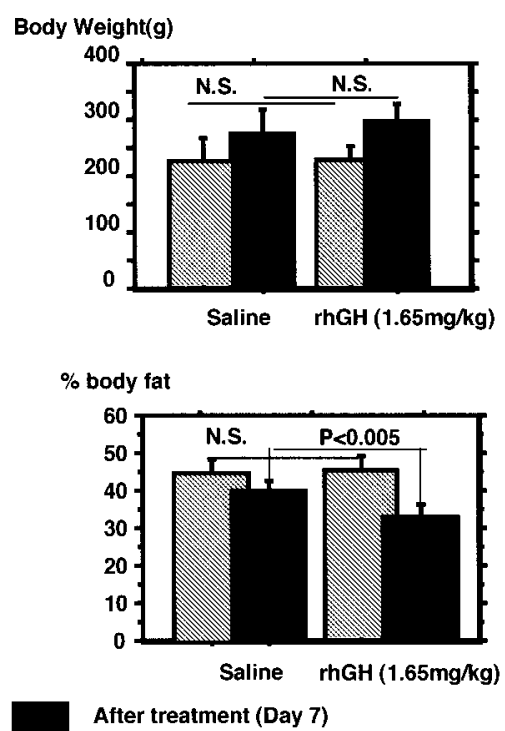

Figure 1 Effect of $\mathrm{GH}$ on body weight and percentage body fat of fatty Zucker rats. The indicated doses of rhGH or saline were administered s.c. for 7 successive days (from day 0 to day 6). Body weight and percentage body fat were determined before the experiments (day 0 ) and after the treatments (day 7 ) as described in Materials and Methods. The percentage body fat of the rats injected with $\mathrm{rhGH}(1.65 \mathrm{mg} / \mathrm{kg})$ for 7 days was significantly lower than that of the control rats which received saline $(P<0 \cdot 005)$.

\section{Materials and Methods}

Male fatty Zucker $(f a / f a)$ rats and their lean littermates $(\mathrm{Fa} /$ ?) were obtained from Kiwa Laboratory Animals Co., Ltd (Wakayama, Japan). Animals were maintained on a $12 \mathrm{~h}$ day/night schedule with continuous ad libitum access to water and standard laboratory chow. All animal experiments were conducted according to the Guidelines of Experimental Animal Care issued by the Japanese Prime Minister's Office and approved by the institutional committee for experimental animals. All hormonal preparations were injected s.c. for 7 successive days (from day 0 to day 6). Recombinant human (rh) GH (Pharmacia \& Upjohn, Stockholm, Sweden) was dissolved in saline and injected s.c. once a day $(0.5 \mathrm{mg} / \mathrm{kg}$ or $1.65 \mathrm{mg} / \mathrm{kg})$. Recombinant human IGF-I (Fujisawa Pharmaceutical Co., Ltd, Osaka, Japan) in $0 \cdot 1 \mathrm{M}$ acetic acid was administered s.c. (200 $\mu \mathrm{g} /$ day) with miniosmotic pumps (Alzat Corp., Palo Alto, CA, USA). Control rats were given saline by the same methods. Body weight and percentage body fat were measured at day 0 and day 7 . Percentage body fat was determined by a bioelectroimpedance method using an SA-2 body composition analyzer for small animals (EM-Scan Inc., Springfield, IL, USA). On the day that they were killed (day 7), the animals were anesthetized, and epididymal and subcutaneous fat tissues were excised, immediately frozen in liquid nitrogen and stored at $-80{ }^{\circ} \mathrm{C}$ until RNA extraction. Serum was also collected and stored at $-20^{\circ} \mathrm{C}$ until analysis.

Total RNA was extracted by the guanidine/ $\mathrm{CsCl}$ method. Leptin mRNA levels were determined by quantitative reverse transcription-PCR (RT-PCR) as reported by Makino et al. (1990) with modifications. One $\mu \mathrm{g}$ of the RNA samples and $0 \cdot 25 \mu \mathrm{g}$ oligo-d $\mathrm{T}_{15}$ primer in $16 \mu \mathrm{l} \mathrm{RT}$ buffer were heated to $95^{\circ} \mathrm{C}$ for $2 \mathrm{~min}$, chilled on ice and incubated at $37^{\circ} \mathrm{C}$ for $30 \mathrm{~min}$ for annealing. The mixtures were incubated at $37^{\circ} \mathrm{C}$ for $60 \mathrm{~min}$ with $100 \mathrm{U}(0.5 \mu \mathrm{l})$ of Moloney murine leukemia virus reverse transcriptase (Gibco-BRL/Life Technologies, Gaithersburg, MD, USA) in a $20 \mu \mathrm{l}$ reaction mixture. Serial dilutions of a standard RNA sample $(0 \cdot 2-2 \mu \mathrm{g})$ were also reversetranscribed simultaneously. Then $1 \mu \mathrm{l}$ of the $\mathrm{RT}$ reaction mixture was mixed with the following solutions: $1 \cdot 0 \mu \mathrm{l}$ $10 \times$ reaction buffer, $0.8 \mu \mathrm{l} 2.5 \mathrm{nM}$ dNTP, $1.0 \mu \mathrm{l}$ primer mixture (10 pmol each) and $0 \cdot 05 \mu \mathrm{l}(0 \cdot 025 \mathrm{U})$ Thermus aquaticus (Taq) DNA polymerase (Gibco-BRL/Life Technologies) and the total volume was adjusted to $10 \mu \mathrm{l}$ with water. The samples were cycle-incubated by denaturation at $94{ }^{\circ} \mathrm{C}$ for $30 \mathrm{~s}$, annealing at $65^{\circ} \mathrm{C}$ for $30 \mathrm{~s}$ and extension at $72{ }^{\circ} \mathrm{C}$ for $60 \mathrm{~s}$. The rat leptin primers were from a previously reported sequence (accession number D49653; Murakami \& Shima 1995). The forward primer (nucleotides 118 to 138 ) was $5^{\prime}$-ACA CCA AAA CCC TCA TCA AGA-3', and the reverse primer (nucleotides 


\section{A. Epididymal Fat}

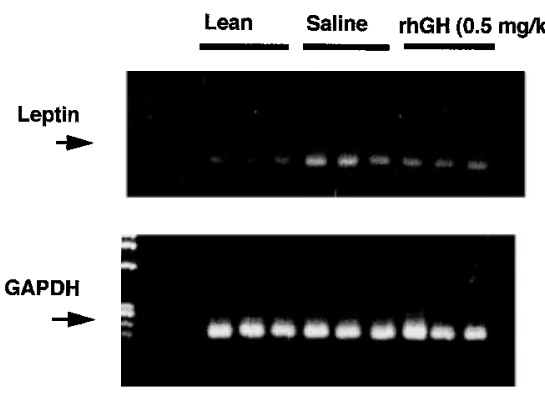

Leptin /GAPDH ratio

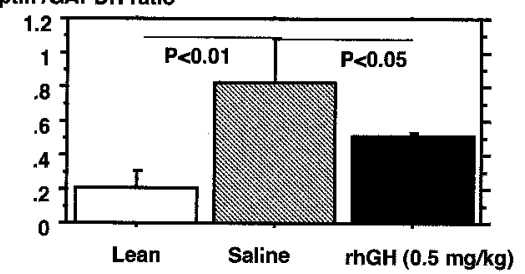

\section{B. Subcutaneous Fat}

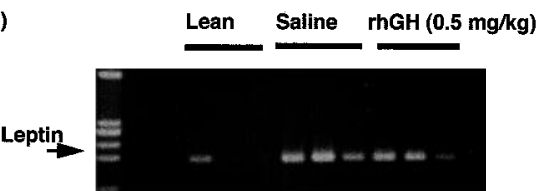

GAPDH

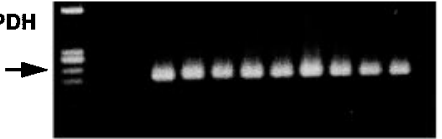

Leptin /GAPDH ratio

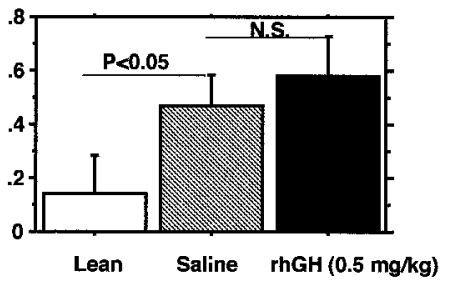

Figure 2 Effect of low-dose GH on leptin mRNA expression in Zucker rats. Saline was injected into lean Zucker rats (Lean) and control fatty Zucker rats (Saline). GH at $0.5 \mathrm{mg} / \mathrm{kg}$ was injected into fatty Zucker rats for 7 successive days. After these treatments, RNA was extracted from the epididymal and subcutaneous fat tissues and leptin mRNA levels were determined as described in Materials and Methods. (A) Leptin mRNA levels in epididymal fat tissue. Upper panel: ethidium bromide staining of the quantitative RT-PCR for leptin and GAPDH mRNA. Lower panel: densitometric analysis of RT-PCR products. The leptin/GAPDH mRNA ratio in epididymal fat tissues of control fatty Zucker rats (Saline) was significantly higher than that in lean Zucker rats (Lean) injected with saline. The leptin/GAPDH mRNA ratio in fatty Zucker rats injected with rhGH was significantly lower than that in fatty Zucker rats injected with saline $(P<0 \cdot 05)$. (B) Leptin mRNA levels in subcutaneous fat tissue. Upper panel: ethidium bromide staining of quantitative RT-PCR for leptin and GAPDH mRNA. Lower panel: densitometric analysis of RT-PCR products. Leptin/GAPDH mRNA ratio of the lean Zucker rats (Lean) was significantly lower than that of control fatty Zucker rats. The leptin/GAPDH mRNA ratio of the fatty Zucker rat treated with rhGH was not different from the control rats.

301 to 283) was $5^{\prime}$-GAA GGC AAG CTG GTG AGG A-3'. The sequences of the glyceraldehyde-3-phosphate dehydrogenase (GAPDH) PCR primers are from rat the GAPDH sequence (accession number M17701). The forward primer (nucleotides 335-352) was $5^{\prime}$-CCA TGG AGA AGG CTG GGG-3', and the reverse primer (nucleotides 512-529) was $5^{\prime}$-CAA AGT TGT CAT GGA TGA-3'. A linear range of expression of the genes was identified through different PCR cycles using the serial dilution of the standard RNA, with the optimal numbers of cycles being 40 for leptin mRNA and 24 for GAPDH mRNA. Then $8 \mu$ of the PCR products were mixed with $2 \mu 15 \times$ stop-dye solution, run on $3 \%$ agarose gels and stained with ethidium bromide. Optical density (OD) values were measured using an image scanner (Sharp Corporation, Osaka, Japan) with the computer software, Image (NIH, Bethesda, MD, USA) and expressed as OD units. To obtain the ratio between leptin and GAPDH mRNA for quantitative analysis, we calculated a linear regression equation between the $\mathrm{OD}$ and amount of RNA in $\mu \mathrm{g}$ using the serial dilutions of the standard RNA sample.

$$
\begin{aligned}
& \mathrm{OD}_{\text {leptin }}=\mathrm{b}_{\text {leptin }}+\mathrm{a}_{\text {leptin }}\times \text { (amount of standard RNA in } \mu \mathrm{g}) \\
& \mathrm{OD}_{\text {GAPDH }}=\mathrm{b}_{\mathrm{GAPDH}}+\mathrm{a}_{\mathrm{GAPDH}} \\
& \times(\text { amount of standard RNA in } \mu \mathrm{g})
\end{aligned}
$$

We calculated a corrected leptin/GAPDH mRNA ratio for each sample using the above equations and expressed the leptin/GAPDH mRNA ratio as follows:

Leptin /GAPDH mRNA ratio $=\left[\mathrm{a}_{\mathrm{GAPDH}}\right.$

$$
\left.\times\left(\mathrm{OD}_{\text {leptin }}-\mathrm{b}_{\text {leptin }}\right)\right] \div\left[\mathrm{a}_{\text {leptin }} \times\left(\mathrm{OD}_{\mathrm{GAPDH}}-\mathrm{b}_{\mathrm{GAPDH}}\right)\right]
$$

Rat IGF-I and rat insulin concentrations were determined using commercial RIA kits from Diagnostic Systems Laboratories Inc., Webster, TX, USA and Amersham Corporation, Little Chalfont, Bucks, UK respectively.

All data are expressed as means \pm s.D. except as indicated. Significance $(P<0 \cdot 05)$ between experimental values was assessed by one-way ANOVA where appropriate. 


\section{A. Epididymal Fat}

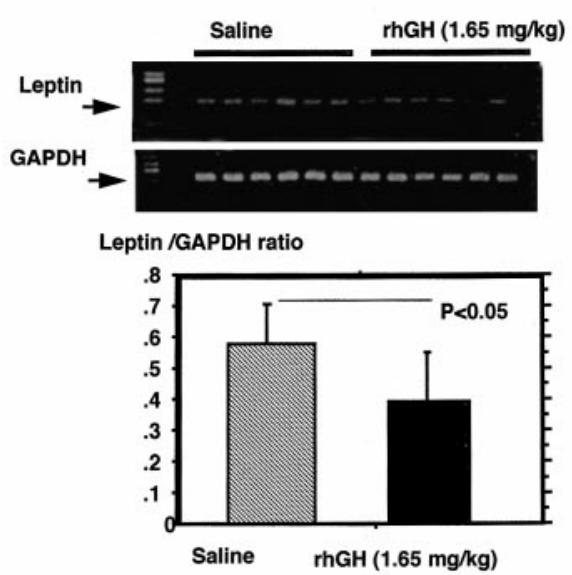

B. Subcutaneous Fat

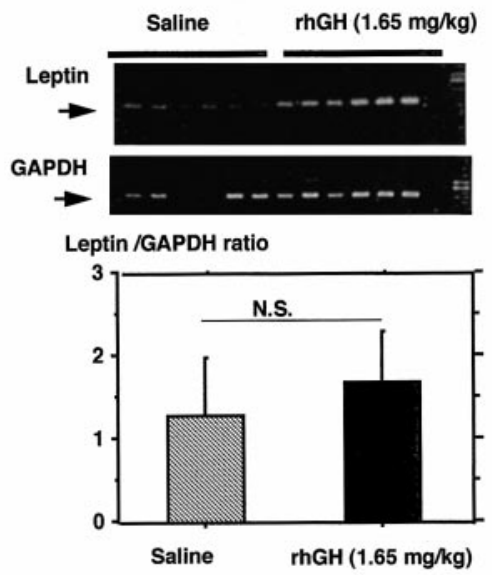

Figure 3 Effect of high-dose growth hormone administration on leptin mRNA expression in Zucker rats. $\mathrm{GH}(1.65 \mathrm{mg} / \mathrm{kg})$ was injected into fatty Zucker rats for 7 successive days. Saline was injected into the control fatty Zucker rats. After these treatments RNA was extracted from the epididymal and subcutaneous fat tissues and leptin mRNA levels were determined as described in Materials and Methods. (A) Leptin mRNA levels in epididymal fat tissue. Upper panel: ethidium bromide staining of the quantitative RT-PCR for leptin and GAPDH mRNA. Lower panel: densitometric analysis of RT-PCR products. Leptin/GAPDH mRNA ratio in fatty Zucker rats injected with rhGH was significantly lower than that of fatty Zucker rats injected with saline $(P<0 \cdot 05)$. (B) Leptin mRNA levels in subcutaneous fat tissue. Upper panel: ethidium bromide staining of the quantitative RT-PCR for leptin and GAPDH mRNA. Lower panel: densitometric analysis of RT-PCR products. The leptin/GAPDH mRNA ratio in the fatty Zucker rats treated with rhGH was not different from that in the control rats.

The calculations were carried out using StatView $4 \cdot 5$ software (Abacus Concepts, Inc., Berkeley, CA, USA).

\section{Results}

We first investigated the effect of a low dose of rhGH $(0.5 \mathrm{mg} / \mathrm{kg})$. After 7 days, the low-dose GH treatment did not change body weight or percentage body fat of the fatty Zucker rats compared with the control fatty rats injected with saline (Fig. 1A). We then determined the leptin mRNA levels in the epididymal and subcutaneous fat tissues of these animals. To assess the reliability of the measurement of leptin mRNA levels, we also treated the lean littermates $(\mathrm{Fa} /$ ?) with saline and determined the mRNA levels in the fat tissues simultaneously. As expected, leptin mRNA levels in both epididymal and subcutaneous fat tissues of the lean rats treated with saline were significantly lower than those in fatty Zucker rats (Fig. 2A,B). The GH treatment significantly decreased leptin mRNA levels in epididymal fat tissue (Fig. 2A) but not in subcutaneous fat tissue (Fig. 2B).

Next we treated fatty Zucker rats with a higher dose of GH $(1.65 \mathrm{mg} / \mathrm{kg})$ for 7 days. In contrast with the lower dose of $\mathrm{rhGH}$, the high-dose $\mathrm{GH}$ treatment decreased percentage body fat, but not the body weight (Fig. 1B). The fact that body weight was not decreased suggests that the effect of GH was not due to decreased food intake or some toxic effect on the rats. We also determined leptin mRNA levels in epididymal and subcutaneous fat tissues of these animals. As seen with the low-dose GH treatment, high-dose GH treatment decreased leptin mRNA levels in epididymal fat tissue but not in subcutaneous tissue (Fig. 3).

As most of the actions of GH are mediated by IGF-I, we also treated fatty Zucker rats with IGF-I. As shown in Fig. 4A, IGF-I did not change body weight or percentage body fat in the rats. Neither did IGF-I change leptin mRNA levels in either epididymal or subcutaneous fat tissues (Fig. 4B). To confirm the metabolic activity of the IGF-I administered, we measured serum IGF-I and insulin concentrations. As shown in Table 1, rhIGF-I administration significantly decreased the serum concentration of IGF-I $(P<0 \cdot 05)$ but not the level of insulin when compared with control rats.

\section{Discussion}

Administration of $\mathrm{GH}$ at the low dose for only 7 days decreased leptin mRNA levels in visceral fat tissue but not 


\section{A. Body weight \& Fat Mass}

Body Weight (g)

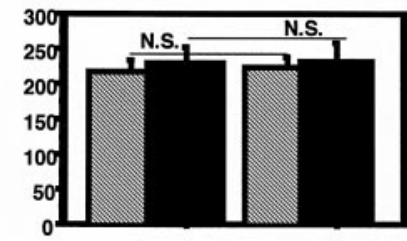

Saline

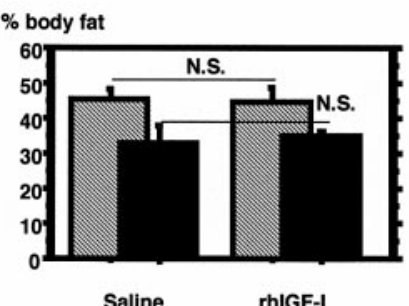

B. Leptin mRNA in Epididymal Fat

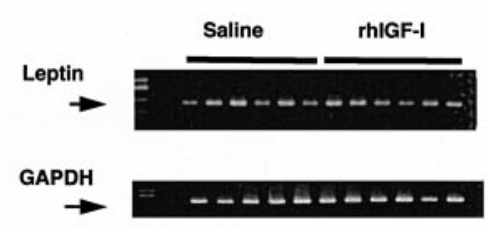

Leptin /GAPDH ratio

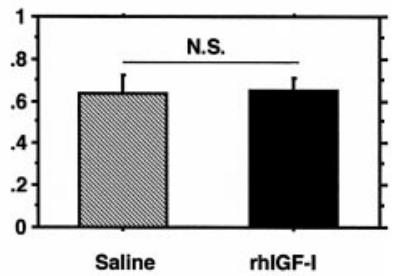

Figure 4 Effect of IGF-I administration on body weight, percentage body fat and leptin mRNA levels. IGF-I was administered by continuous infusion ( $200 \mu \mathrm{g} /$ day) for 7 days. Control rats were administered saline by the same method. After determination of body weight and percentage body fat, RNA was extracted from the fat tissues as described in Materials and Methods. (A) Body weight and percentage body fat. Upper panel: the body weights of the fatty Zucker rats treated with rhlGF-I showed no significant difference from those of the control rats before the experiment (day 0, light shading) and after the experiment (day 7, dark shading). Lower panel: the percentage body fat of the fatty Zucker rats treated with rhIGF-I showed no significant difference from that of the control rats. (B) Leptin mRNA levels in epididymal fat tissue of the fatty Zucker rats. Upper panel: ethidium bromide staining of the quantitative RT-PCR for leptin and GAPDH mRNA. Lower panel: densitometric analysis of the RT-PCR. Leptin/GAPDH mRNA ratio of the epididymal fat tissue of the fatty Zucker rats treated with IGF-I showed no significant difference compared with that in the control rats.

in subcutaneous fat tissue of the fatty Zucker rats. This treatment did not change the percentage body fat, whereas the high-dose administration decreased both percentage body fat and leptin mRNA levels in visceral fat tissue. These observations suggest that the decrease in leptin mRNA expression in visceral fat tissue is one of the early markers of the decrease in fat tissue on $\mathrm{GH}$ administration. Florkowski et al. (1996) also reported that administration of GH to adult patients with GH deficiency decreased both body fat and plasma leptin concentrations within 2 months. As the decreased leptin concentrations correlated well with the decreased percentage body fat, they speculated that GH reduced leptin production by reducing fat mass rather than by a direct action on fat tissue. However, our finding that leptin mRNA expression was

Table 1 Effect of rhIGF-I infusion on serum IGF-I and insulin concentrations in fatty Zucker rats. Values are means \pm S.D.

\begin{tabular}{llll} 
& \multicolumn{1}{l}{ IGF-I $(\mathrm{ng} / \mathrm{ml})$} & & Insulin $(\mathrm{ng} / \mathrm{ml})$ \\
$\begin{array}{l}\text { Saline } \\
\text { rhIGF-I }\end{array}$ & $2619 \cdot 6 \pm 501 \cdot 1$ & & $23 \cdot 42 \pm 6 \cdot 03$ \\
$1875 \cdot 0 \pm 415 \cdot 2^{*}$ & & $21 \cdot 44 \pm 4 \cdot 57$ \\
\hline
\end{tabular}

*Statistically significantly different from value for saline-treated rats $(P<0 \cdot 05)$. reduced before any reduction in percentage body fat suggests that GH may directly alter leptin gene expression in the fat tissue. Supporting this hypothesis, we recently found that leptin concentrations in patients with acromegaly (high serum GH concentration) were significantly lower than those of normal subjects after correction for percentage body fat (Miyakawa et al. 1998). The data also suggest that acromegaly affects leptin production in human adults. Therefore, in addition to the reduction of fat tissue observed in patients with acromegaly and GH-treated fatty Zucker rats, GH may also directly inhibit leptin production in fat tissue.

Our finding that GH decreased leptin mRNA levels in visceral fat tissue but not in subcutaneous tissue re-emphasizes the difference between so-called central fat tissue and peripheral fat tissue. The lipolytic activity of human adipose tissue is well known to have regional differences and to be regulated by several hormones and parahormones. In obese subjects the regional variations in the action of catecholamines on lipolysis are enhanced. Decreased $\beta_{2}$-adrenergic receptor action and increased activity of $\alpha_{2}$-adrenergic adrenoreceptors, in combination with defects in hormone-sensitive lipase function, inhibit the lipolytic effect of catecholamines in subcutaneous fat 
cells. In visceral fat cells, however, increased activity of $\beta_{2}$-adrenergic receptors and decreased activity of $\alpha_{2^{-}}$ adrenoreceptors augment the lipolytic response (Arner 1995). Therefore, GH would be expected to have a more potent effect on visceral fat tissue.

The finding that IGF-I does not change percentage body fat or leptin mRNA levels in visceral fat tissue also suggests that the action of $\mathrm{GH}$ on fat tissue is not mediated by GH-induced IGF-I in fatty Zucker rats. In contrast with our data, IGF-I administration decreased leptin mRNA in epididymal fat tissue of hypophysectomized rats (Boni-Schnetzler et al. 1996). However, insulin levels in the hypophysectomized rats were lower than in control rats, and the authors speculated that IGF-I decreased leptin mRNA levels at low insulin levels by an unexplained mechanism. In fatty Zucker rats, serum insulin levels were significantly higher than those in lean littermates. Therefore, the insulinomimetic effect of IGF-I may not be sufficient to elicit any metabolic effect on the fat tissue in fatty Zucker rats. However, the fact that the rat IGF-I concentration in rats infused with rhIGF-I was significantly lower than that in rats infused with saline suggests that rhIGF-I inhibits GH secretion from the pituitary glands and decreases intrinsic IGF-I production. Therefore, the dose of IGF-I that we administered must be sufficient to induce metabolic action in the rats.

$\mathrm{GH}$ has been reported to regulate leptin mRNA expression and fat cell differentiation in vitro (Chen et al. 1998). GH reduced leptin mRNA levels in porcine S-V cells in primary culture after 6 days of adipocyte differentiation when it was added with insulin, but GH had no effect on leptin mRNA levels and adipocyte differentiation for the first 3 days of culture. Therefore, the action of $\mathrm{GH}$ on adipocytes might be dependent on insulin and the stage of adipocyte differentiation. In this manner, $\mathrm{GH}$ could elicit more profound effects on the fat tissues of fatty Zucker rats because their serum insulin levels are elevated and their fat tissues possess more mature preadipocytes than control littermates. However, further studies are necessary to elucidate the mechanism of action of GH on leptin gene expression.

\section{References}

Ahmad I, Steggles AW, Carrillo AJ \& Finkelstein JA 1990

Developmental changes in levels of growth hormone mRNA in Zucker rats. Journal of Cell Biochemistry 43 59-66.
Arner P 1995 Differences in lipolysis between human subcutaneous and omental adipose tissues. Annals of Medicine 27 435-438.

Boni-Schnetzler M, Gosteli-Peter MA, Moritz W, Froesch ER \& Zapf J 1996 Reduced ob mRNA in hypophysectomized rats is not restored by growth hormone $(\mathrm{GH})$, but further suppressed by exogenously administered insulin-like growth factor (IGF)-I. Biochemical Biophysical Research Communication 225 296-301.

Campfield LA, Smith FJ \& Burn P 1996 The OB protein (leptin) pathway-a link between adipose tissue mass and central neural networks. Hormone and Metablic Research 28 619-632.

Chen XL, Hausman DB, Dean RG \& Hausman GJ 1998 Hormonal regulation of leptin mRNA expression and preadipocyte recruitment and differentiation in porcine primary cultures of $\mathrm{S}-\mathrm{V}$ cells. Obesity Research 6 164-172.

Chua SCN Jr, Chung WK, Wu-Peng XS, Zhang Y, Liu SM, Tartaglia L \& Leibel RL 1996 Phenotypes of mouse diabetes and rat fatty due to mutations in the OB (leptin) receptor. Science $\mathbf{2 7 1}$ 994-996.

Deoer H, Block G-J \& Van der Veen EA 1995 Clinical aspects of growth hormone deficiency in adults. Endocrine Review 16 63-86.

Fain JN, Kovacev VP \& Scow RO 1965 Effect of growth hormone and dexamethasone on lipolysis and metabolism in isolated fat cells of the rat. Journal of Biological Chemistry 240 3522-3529.

Florkowski CM, Collier GR, Zimmet PZ, Livesey JH, Espiner EA \& Donald RA 1996 Low-dose growth hormone replacement lowers plasma leptin and fat stores without affecting body mass index in adults with growth hormone deficiency. Clinical Endocrinology 45 769-773.

Goodman HM 1968 Multiple effects of growth hormone on lipolysis. Endocrinology 83 300-308.

Makino R, Sekiya T \& Hayashi K 1990 Evaluation of quantitative detection of mRNA by the reverse transcription-polymerase chain reaction. Technique 2 295-301.

Miyakawa M, Tsushima T, Murakami H, Isozaki O, Demura H \& Tanaka T 1998 Effect of growth hormone on serum concentrations of leptin: study in patients with acromegaly and growth hormone deficiency. Journal of Clinical Endocrinology and Metabolism $\mathbf{8 3}$ 3476-3479.

Murakami T \& Shima K 1995 Cloning of rat obese cDNA and its expression in obese rats. Biochemical and Biophysical Research Communications 209 944-952.

Tartaglia LA, Dembski M, Weng X, Deng N, Culpepper J, Devos R, Richards GJ, Campfield LA, Clark FT, Deeds J, Muir C, Sanker S, Moriaty A, Mure KJ, Smutko JS, Mays GG, Woolf EA, Monroe CA \& Tepper RI 1995 Identification and expression cloning of a leptin receptor, OB-R. Cell 83 1263-1271.

Thorner MO, Vance ML, Horvath E \& Kovacs K 1992 The anterior pituitary. In Williams Textbook of Endocrinology, edn 8, ch 6, pp 221-310. Eds JD Wilson \& DW Foster. Philadelphia: WB Saunders Company

Zhang Y, Proenca R, Maffei M, Barone M, Leopold L \& Friedman JM 1994 Positional cloning of the mouse obese gene and its human homologue. Nature 372 425-432.

Received 10 November 1998

Accepted 26 January 1999 